\title{
FAKTOR YANG BERHUBUNGAN TERHADAP CARA MENGATASI MUAL MUNTAH PADA KEHAMILAN TRIMESTER I
}

\author{
Nelfi Sarlis \\ D III Kebidanan, Akademi Kebidanan Sempena Negeri Pekanbaru \\ Jl. Soekarno Hatta, Gang Handayani I No I Arengka Pekanbaru-Riau-Indonesai \\ Email : sarlisnelfi@ gmail.com
}

Kata Kunci: Pengetahuan, sikap, mual muntah

Keywords: Knowledge, attitude, nausea and vomiting

Info Artikel

Tanggal dikirim : 5 Juni 2020

Tanggal direvisi : 19 Juli 2020

Tanggal Diterima: 19 Juli 2020 DOI:

10.36341/jomis.v4.i2.1317

Creative Commons AttributionNonCommercial-ShareAlike 4.0 International License.

\begin{abstract}
ABSTRAK :
Mual muntah sering dialami oleh ibu hamil trimester I. Keadaan ini merupakan hal yang wajar dan sering terjadi pada kehamilan terutama pada trimester pertama, Mual biasanya terjadi pada pagi hari, kasus ini dapat terjadi hampir 50\% ibu hamil dan banyak terjadi pada umur kehamilan 6-12 minggu. Kejadian mual dan muntah dapat mengganggu sehingga dapat membuat ketidakseimbangan cairan pada jaringan ginjal dan hati menjadi nekrosis. Ibu hamil cenderung meremehkan rasa mual dan muntah akibat kurangnya pengetahuan, sehingga timbulnya sikap negatif dalam upaya penanganan emesis gravidarum. Tujuan penelitian ini yaitu untuk mengetahui Faktor yang berhubungan terhadap cara mengatasi mual muntah pada kehamilan trimester 1. Penelitian ini menggunakan metode kuantitatif dengan desain cross sectional dimana variabel independennya adalah Pengetahuan dan Sikap sedangkan variabel dependennya adalah cara mengatasi mual muntah. Tehnik Pengambilan sampel yaitu consecutive sampling dengan jumlah responden 72 ibu hamil. Berdasarkan hasil uji chi square didapatkan variable pengetahuan berhubungan dengan cara mengatasi mual muntah dengan $\mathrm{p}=0,008$ dimana nilai $\alpha<0,1$ maka, Ha diterima berarti ada hubungan pengetahuan ibu hamil terhadap cara mengatasi mual muntah sedangakan variable sikap didapatkan $p=0,000$ dimana nilai $\alpha<0,1$ maka, Ha diterima berarti ada hubungan sikap terhadap cara mengatasi mual muntah pada ibu hamil trimester I. Perlu ditingkatkan lagi pengetahuan dan sikap masyarakat khususnya ibu hamil tentang cara engatasi mual muntah pada kehamilan trimester I.
\end{abstract}

\section{ABSTRACT :}

Every pregnant woman in the first trimester experiences nausea and vomiting. This situation is natural and often occurs in pregnancy, especially in the first trimester. Nausea usually occurs in the morning, this case can occur almost $50 \%$ of pregnant wowen and many occur at 6-12 weeks. Expectant mothers tend to belittle the ignorance of nausea and vomit, giving rise to a negative attitude in dealing with the gravidarum emesisThe purpose of this study was to determine the relationship between knowledge and attitudes of pregnant women on how to cope with vomiting nausea in pregnancy trimester 1 in the work area of Payung Sekaki health center in Pekanbaru. This study uses a quantitative method with a cross sectional, so that the number of samples obtained was 71 respondents. Sampling used consecutive sampling technique, nominal and ordinal measuring scales, questionnaire research instruments and univariate and bivariate data collection. Based on the results of the chi square test obtained the knowledge variable is related to how to overcome nausea and vomiting with $p=0.008$ where the value of $\alpha<0.1$ then, Ha accepted means there is a relationship between knowledge and attitudes of pregnant women on how to cope with nausea vomiting while the variable obtained $p=0,000$ where the value of $\alpha<0,1$ in the working area of payung sekaki health center in Pekanbaru in 2019. Advised to puskesmas payung sekaki pekanbaru to try to increase public knowledge abaout nausea vomiting in pregnancy and the attitude of pregnant women to overcome nause and vomiting. By providing counseling to pregnant women abaout nausea and vomiting in pregnancy. 


\section{PENDAHULUAN}

Mual muntah sering dialami ibu hamil pada trimester pertama. Hal ini sangat wajar tejadi apalagi pada kehamilan trimester pertama [1]. Mual biasanya terjadi pada pagi hari, tetapi dapat juga terjadi pada malam hari. Dalam penelitian mengatakan sekitar $80 \%$ dari wanita melaporkan bahwa mual muntah yang mereka alami berlangsung sepanjang hari, hanya $1,8 \%$ melaporkan gejala yang terjadi hanya di pagi hari. Gejala-gejala ini kurang lebih terjadi 6 minggu setelah HPHT dan berlangsung selama lebih kurang 10 minggu [2]

Pola makan yang buruk pada minggu-minggu awal kehamilan ataupun sebelum terjadi kehamilan, kurang tidur atau kurang istirahat dan stress juga dapat memperberat rasa mual dan muntah [3]. Beberapa hal yang dapat dilakukan untuk mengurangi rasa mual yaitu dengan mengkonsumsi makanan seimbang, cukup bergerak dan beristirahat. Oleh karena itu calon ibu diharapkan memiliki pengetahuan yang cukup mengenai mual agar ibu dapat menentukan sikap untuk mengatasi masalahnya yang terjadi pada awal kehamilan [4]

Sebagian besar ibu hamil 70-80\% mengalami morning sickness dan sebanyak $1-2 \%$ dari semua ibu hamil mengalami morning sickness yang ekstrim [5]. Dari hasil penelitian Susanti (2019) Berdasarkan hasil analisa hubungan antara pengetahuan dan perilaku ibu hamil dalam mencegah mual muntah, dapat diketahuan bahwa ada hubungan signifikan antara pengetahuan dengan sikap ibu hamil dalam mencegah mual muntah, dengan nilai sifnifikan, $(0,033)>\alpha(0,05)[6]$

Ibu hamil harus mampu beradaptasi terhadap mual dan muntahnya, jika tidak mampu beradaptasi maka bisa menimbulkan akibat buruk baik pada ibu hamil maupun pada janin yang dikandungnya [7]. Dari hasil penelitian terdahulu didapatkan bahwa hiperemesis gravidarum dapat mengakibatkan bayi lahir dengan BBLR [8] . Dengan asupan nutrisi yang baik selama kehamilan, maka akan lahir bayi yang lebih berkualitas. Namun, jika asupan nutrisi menurun maka wanita hamil tersebut akan mengalami penurunan berat badan dan hal ini juga akan berdampak buruk pada janin yang dikandungnya [9] Dalam upaya mencegah dampak buruk pada masa kehamilan, diperlukan pengetahuan, sikap dan perilaku yang mendukung menuju perubahan yang lebih baik, khususnya bagi ibu primigravida [10]

Berdasarkan latar belakang di atas, pengetahuan dan sikap ibu hamil tentang cara mengatasi mual muntah sangat penting karna penetahuan yang kurang dapat membahayakan ibu serta janin yang dikandungnya. Pengetahuan sangat berpengaruh terhadap terbentukknya sikap seseorang. Hal ini yang membuat peneliti berminat untuk melakukan penelitian tentang " Faktor yang berhubungan terhadap cara mengatasi mual muntah pada kehamilan trimester I ". Penelitian ini bertujuan untuk mengetahui hubungan pengetahuan dan sikap ibu hamil terhadap cara mengatasi mual muntah pada kehamilan trimester I.

\section{TINJAUAN PUSTAKA}

Penelitian yang terkait dengan penelitian ini adalah penelitian Susanti (2019) Berdasarkan hasil analisa hubungan antara pengetahuan dan perilaku ibu hamil tentang manfaat jahe dalam mencegah mual muntah diwilayah kerja Puskesmas Botania Kota Batam, dapat diketahuan bahwa ada hubungan signifikan antara pengetahuan dengan sikap ibu hamil dalam mencegah mual muntah di wilayah kerja puskesmas Botania Kota Batam, dengan nilai sifnifikan, $(0,033)>\alpha(0,05)[6]$ 
Penelitian ini sejalan dengan penelitian (Anita, 2017). Berdasarkan hasil analisa hubungan pengetahuan dan sikap ibu hamil dengan tindakan pencegahan mual muntah di klinik junita kecamatan tapian dolok kabupaten simalungun, dapat diketahui bahwa ada hubungan signifikan antara pengetahuan terhadap cara mengatasi mual muntah pada ibu hamil nilai sig. $(0,000)<\alpha(0,05)[11]$

Penelitian ini sejalan dengan penelitian Latifah dkk tahun 2017 tentang efektifitas Self Managemen Module (Promosi Pendidikan) dalam mengatasi Mornng Sickness bahwa pengetahuan sangat berpengaruh terhadap mengatasi mual muntah dengan nilai sifnifikan, $(0,000)>\alpha(0,05)[12]$

Penelitian yang terkait dengan penelitian ini adalah penelitian Wiwik $\mathrm{O}$ dkk (2019) didapat uji chisquare diperoleh hasil $\mathrm{P}$ value $=0,049<\alpha(0.05)$ sehingga ada hubungan antara pengetahuan dengan sikap ibu hamil dalam mencegah kejadian hyperemesis gravidarum di wilayah kerja Puskesmas Padalarang [13]

Hasil penelitian ini sejalan dengan hasil penelitian terdahulu yaitu terdapat hubungan antara Pengetahuan dan sikap ibu hamil terhadap cara mengatasi mual muntah pada kehamilan trimester I.

\section{METODE PENELITIAN}

Jenis penelitian ini adalah analisis kolerasi, dengan pendekatan cross sectional untuk mengetahui hubungan pengetahuan dan sikap ibu hamil terhadap cara mengatasi mual muntah pada kehamilan trimester pertama. Penelitian ini dilaksanakan dari bulan September tahun 2018- Maret tahun 2019 yaitu di wilayah kerja Puskesmas Paung Sekaki Pekanbaru. Populasi dalam penelitian ini adalah seluruh ibu hamil yang ada diwilayah kerja Puskesmas Payung Sekaki Pekanbaru.

Pengambilan sampel pada penelitian ini adalah consecutive sampling. Sampel diperoleh berdasarkan data dari Puskesmas Payung Sekaki. Sampel penelitian yang dipakai sebanyak 72 ibu hamil.

Instrumen penelitian yang digunakan dalam pengumpulan data yaitu kuesioner tentang pengetahuan dan sikap ibu hamil. Variabel independent dalam penelitian ini adalah pengetahuan, sikap sedangkan variabel dependennya adalah cara mengatasi mual muntah.

Analisa data yang digunakan adalah Univariat dan Bivariat. Analisis bivariat menggunakan uji chi square Dengan pedoman dalam menerima hipotesis : apabila nilai probabilitas $(p)>0,1$ maka Ho ditolak. Apabila $(p)<0,1$ maka Ho diterima.

\section{HASIL DAN PEMBAHASAN}

Tabel 1.

Hubungan pengetahuan ibu hamil terhadap cara mengatasi mual muntah.

\begin{tabular}{|c|c|c|c|c|c|c|c|c|}
\hline \multirow[t]{3}{*}{ Pengetahuan ibu } & \multicolumn{4}{|c|}{ Mual muntah } & \multirow{2}{*}{\multicolumn{2}{|c|}{ Total }} & \multirow{3}{*}{$\mathrm{P}$} & \multirow{3}{*}{$\alpha$} \\
\hline & \multicolumn{2}{|c|}{ Diatasi } & \multicolumn{2}{|c|}{ Tidak diatasi } & & & & \\
\hline & $\mathrm{N}$ & $\%$ & $\mathrm{~N}$ & $\%$ & $\mathrm{~N}$ & $\%$ & & \\
\hline Baik & 17 & 68 & 8 & 32 & 25 & 100 & \multirow{4}{*}{0,008} & \multirow{4}{*}{0,1} \\
\hline Cukup & 4 & 25 & 12 & 75 & 16 & 100 & & \\
\hline \multirow[t]{2}{*}{ Kurang } & 10 & 33,3 & 20 & 66 & 30 & 100 & & \\
\hline & 31 & 43 & 40 & 56 & 71 & 100 & & \\
\hline
\end{tabular}


Dari hasil uji chi-square dengan menggunakan system komputerisasi menunjukan hasil $\mathrm{P}$-value $=0,008$ dan derajat kesalahan 0,1 maka Ho ditolak dan
Ha diterima artinya ada hubungan pengetahuan terhadap cara mengatasi mual muntah pada ibu hamil trimester 1 .

Tabel 2.

Hubungan sikap terhadap cara mengatasi mual muntah

\begin{tabular}{|c|c|c|c|c|c|c|c|c|}
\hline \multirow[t]{3}{*}{ Sikap Ibu Hamil } & \multicolumn{4}{|c|}{ Mual Muntah } & \multirow{2}{*}{\multicolumn{2}{|c|}{ Total }} & \multirow{3}{*}{$\mathbf{P}$} & \multirow{3}{*}{$\alpha$} \\
\hline & \multicolumn{2}{|c|}{ Diatasi } & \multicolumn{2}{|c|}{ Tidak Diatasi } & & & & \\
\hline & $\mathrm{N}$ & $\%$ & $\mathrm{~N}$ & $\%$ & $\mathrm{~N}$ & $\%$ & & \\
\hline Sangat Buruk & 4 & 22,2 & 14 & 77,8 & 18 & 100 & & \\
\hline Tidak Setuju & 2 & 12,5 & 14 & 87,5 & 16 & 100 & & \\
\hline Cukup Netral & 10 & 76,9 & 3 & 23,1 & 13 & 100 & 0,00 & 0,1 \\
\hline Setuju & 2 & 18,2 & 9 & 81,8 & 11 & 100 & & \\
\hline Sangat Setuju & 13 & 100 & 0 & 0,0 & 13 & 100 & & \\
\hline Jumlah & 31 & 43,7 & 40 & 56,3 & 71 & 100 & & \\
\hline
\end{tabular}

Dari hasil uji chi-square dengan menggunakan system komputerisasi menunjukan hasil $\mathrm{P}$-value $=0,000$ dan derajat kesalahan 0,1 maka Ho ditolak dan Ha diterima artinya ada hubungan sikap terhadap cara mengatasi mual muntah pada Ibu hamil trimester 1.

Hasil penelitian menyatakan dari 71 responden ibu yang pengetahuan kurang sebanyak 30 orang $(42,3 \%)$, ibu yang pengetahuan cukup sebanyak 16 orang $(22,5 \%)$, dan ibu yang pengetahuan baik sebanyak 25 orang $(35,2 \%)$.

Pengetahuan adalah hasil "tahu" dari manusia, yang sekedar menjawab pertanyaan "what" misalnya apa benda, apa binatang, apa alam dan sebagainya [14]. Hal ini dapat terjadi setelah seseorang melakukan penginderaan terhadap suatu objek tertentu. Penginderaan terjadi melalui panca indra manusia, yakni : indra penglihatan, pendengaran, penciuman, rasa dan raba. Sebagian besar pengetahuan manusia diperoleh mulai mata dan telinga
Pengetahuan atau kognitif merupakan domain yang sangat penting akan terbentuknya tindakan seseorang. Karena dari pengalaman dan penelitian ternyata perilaku yang didasari oleh pengetahuan akan lebih langgeng dari pada perilaku yang tidak didasari oleh pengeteahuan [15]

Menurut asumsi peneliti, dari hasil penelitian ini dapat disimpulkan bahwa masih banyak ibu yang memiliki pengetahuan yang kurang, dikarenakan masih banyak ibu tidak tahu tentang cara untuk mengatasi mual muntah yang dialaminya.

Penelitian ini sejalan dengan penelitian Anita, S (2016). Berdasarkan hasil analisa hubungan pengetahuan dan sikap ibu hamil dengan tindakan pencegahan mual muntah di klinik junita kecamatan tapian dolok kabupaten simalungun, dapat diketahui bahwa ada hubungan signifikan antara pengetahuan terhadap cara mengatasi mual muntah pada ibu hamil nilai sig. $(0,000)<\alpha(0,05)[11]$ 


\section{KESIMPULAN}

Terdapat hubungan antara Pengetahuan dan sikap ibu hamil terhadap cara mengatasi mual muntah pada kehamilan trimester I.

\section{DAFTAR PUSTAKA}

[1] Hutahaean, perawatan antenatal. Jakarta: salemba medika, 2013.

[2] P. H. Elsa V, "Hubungan paritas ibu hamil Trimester I dengan kejadian emesis gravidarum di Puskesmas Teras," Kebidanan, vol. IV, no. 02, pp. 35-48, 2017.

[3] Nugroho, Obgyn : Obstetri Dan Genekologi. Yogyakarta: Nuha Medika, 2014.

[4] R. S. Zaerotun S, "Hubungan karakteristik, paritas dan pengetahuan dengan upaya mengatasi mual muntah pada kehamilan trimester I dengan hiperemesis gravidarum di rumah sakit pku muhammadiyah gubug kabupaten grobogan,” p. 13, 2016.

[5] S. C. R. L. Wijayanti A R, "Gambaran pengetahuan ibu hamil trimester I tentang Hiperemesis Gravidarum," vol. 6, no. 2, pp. 131138, 2017.

[6] Susanti, Menara Ilmu, vol. XIII, no. Hubungan pengetahuan dengan perilaku ibu hamil tentang manfaat jahe dalam mengatasi mual muntah pada kehamilan trimester I, p. 7 , 2019.

[7] N. N. Mudlikah S, "Hubungan Pengetahuan dan Sikap Ibu Hamil terhadap Mual Muntah Kehamilan dengan Waktu Mual," vol. 5, no. November, pp. 1-6, 2019.

[8] A. Magfirah, "RIWAYAT HIPEREMISIS GRAVIDARUM TERHADAP RISIKO KEJADIAN Hiperemisis Gravidarum Event Risk Low Birth Weight Babies," Idea Nurs. J., vol. IV, pp. 30-35, 2013.
[9] Y. Retnowati, "Faktor-Faktor Yang Mempengaruhi Terjadinya Emesis Gravidarum Pada Kehamilan Trimester I Di Puskesmas Pantai Amal," J. Borneo Holist. Heal., vol. 2, no. 1, pp. 40-56, 2019.

[10] N. Jannah, Buku Ajar Asuhan Kebidanan kehamilan. Yogyakarta: CV Andi OF SET, 2012.

[11] Anita ( Universitas Sari Mutiara Indonesia), "Hubungan pengetahuan dan sikap ibu hamil dengan tindakan pencegahan emesis gravidarum selama kehamilan," Matern. dan Neonatal, vol. 2, p. 12, 2017.

[12] X. Dwlidk and W. L. Zl, "Efektifitas Self Management Module dalam Mengatasi Morning Sickness," JKP, vol. 5, no. April, 2017.

[13] O. Wiwik, S. Niman, and Y. A. Susilowati, "Mencegah Kejadian Hiperemesis Gravidarum," pp. 917, 2016.

[14] Notoatmodjo, Buku Ajar Asuhan Kebidanan Kehamilan. Yogyakarta, 2012.

[15] S. Notoatmodjo, Promosi Kesehatan dan Perilaku Kesehatan. Jakarta: Rineka Cipta, 2012. 